\title{
THE CURRENT VIEW ON THE USE OF RECONSTRUCTION MATERIALS IN DENTISTRY
}

\author{
Radka Vrbova ${ }^{a, *}$, Pavel Bradna $^{a}$, Martin Bartos $^{a}$, Lucie Himmlova $^{a}$, \\ TOMAS HORAZDOVSKY ${ }^{b}$
}

${ }^{a}$ Institute of Dental Medicine, First Faculty of Medicine, Charles University and General University Hospital in Prague, Prague, Czech Republic

${ }^{b}$ Department of Physics, Faculty of Mechanical Engineering, Czech Technical University in Prague, Prague, Czech Republic

* corresponding author: vrbova@vus.cz

Abstract. The hardest tissue in the human body is the enamel which covers the anatomical crowns of teeth. It must be resistant to mechanical stress and the chemical attack of many substances from food, drinks and products of the metabolism of bacteria present in the oral cavity. These low $\mathrm{pH}$ substances dissolve the mineral components of enamel, cause tooth demineralization, and lead to decay or erosion damage with the irreversible loss of dental hard tissues and the necessity of their reconstruction. The range of dental materials intended for dental tissue reconstruction is extensive. Dental amalgam can be mechanically applied into the strongly stressed lateral segments of teeth. The use of amalgam is, however, in decline, with the possible health risks attributed to it, coupled with the need to extensively prepare tooth tissue promoting a shift towards using aesthetically and biologically favourable dental ceramic and polymeric materials instead. Current developments also concentrate on these materials to reinforce this, with polymeric composite materials based on methacrylates with varying amounts of inorganic fillers at the forefront. These materials are distinguished by their good mechanical and aesthetic properties and wear resistance. However, polymerization shrinkage and a strong hydrophobic nature does not allow for their direct bonding to hard dental tissues. Risks associated with the release of residual free monomers from the structure to the environment, which may cause health complications, mainly allergic reactions in sensitive individuals, have been monitored recently. Further development in the field of composite materials aims to reduce or completely eliminate these negatives.

KEYWORDS: hard dental tissues, tooth decay, erosion, dental materials.

\section{INTRODUCTION}

Teeth are specific formations in the oral cavity which are mainly composed from hard tissues such as enamel, dentine and cementum. Enamel covers the surface of anatomical crowns and is the hardest tissue in the human body due to the high content of mineral substances. The so-called prismatic structure is typical for enamel, with closely spaced prisms bound with interprismatic substance (Fig. 1 1). Enamel prisms with a diameter of 4-8 $\mu \mathrm{ms}$ are formed predominantly from hydroxyapatite nanocrystals. The interprismatic mass also contains proteins, except hydroxyapatite, which serve as a binder for the individual prisms. Dentine is mineralized less than enamel, is softer, and contains about 20-30 vol. \% of proteins and 20-30 vol. \% of water, and is biologically active compared to enamel. Typical structural elements are known as dentinal tubules, canals in the dentine where extensions of the odontoblasts exist alongside dentinal fluid (Fig. 1p).

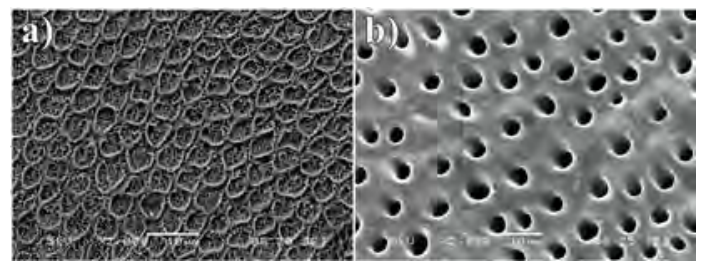

Figure 1. a) Prismatic structure of enamel after phosphoric acid etching (cross-section); b) The surface of dentin with dentinal tubules after phosphoric acid etching (cross-section). (SEM, JSM5500-LV, Jeol, Tokyo, Japan).

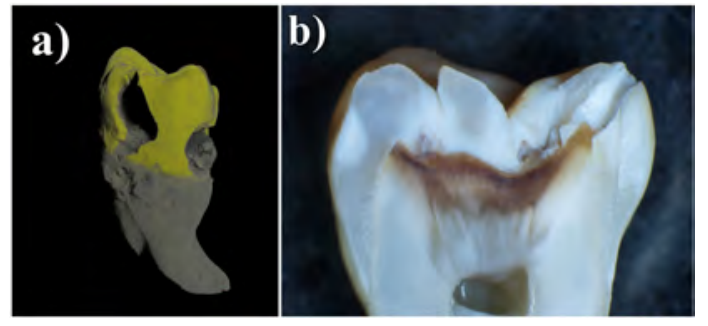

Figure 2. a) 3D model of the damaged tooth by caries from micro-CT (SkyScan 1272, Bruker, Belgium); b) The longitudinal cross section of a tooth with tooth decay in the enamel and dentin (optical microscope Olympus, SMZ 2MT, Japan). 


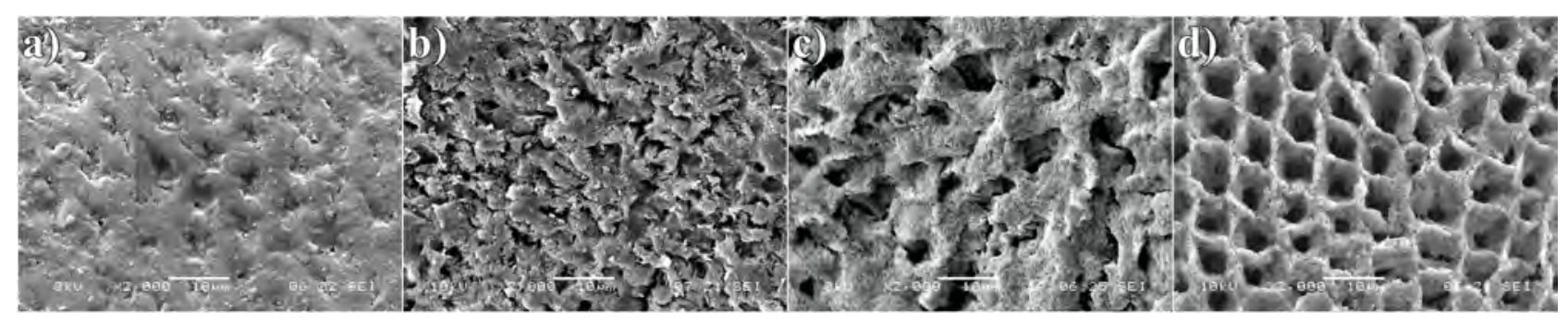

Figure 3. The surface of enamel exposed to drinks for 12 hours: a) intact enamel; b) Coca-Cola, pH 2.5; c) Fanta, pH 2.8; d) Sprite pH 2.7. (SEM, JSM5500-LV, Jeol, Tokyo, Japan).

\section{The TYPICAL DAMAgES OF HARD DENTAL TISSUES}

\subsection{TоOTH DECAY}

Due to the effect of products of the metabolic conversions of cariogenic bacteria present in dental plaque, there is a local demineralization in the subsurface layers of enamel. If the process reaches the dentineenamel border, it will break the surface layers of the enamel and will lead to the formation of a cavity (Fig. $2 \mathrm{a}, \mathrm{b})$.

\subsection{EROSION}

In the case of dental tissue erosion, the demineralization is of non-bacterial origin. It results from the attack of substances with high acidity and simple sugars content. From this point of view, so-called "soft drinks" are very aggressive with a low $\mathrm{pH}$, containing e.g. phosphoric acid or citric acid (Fig. 3 b, c, d). They cause the dissolution of enamel mineral components; reduce its surface hardness and resistance to abrasion or mechanical stress.

The result of the above-mentioned conditions may be the loss of dental hard tissues with the necessity of their reconstruction, which is often complicated and costly. Additionally, the lifetimes of reconstructions are always limited.

\section{Polymeric materials For the RECONSTRUCTION OF HARD DENTAL TISSUES}

The range of dental materials intended for the reconstruction of lost or damaged dental tissues, whether as a result of carious processes, extensive erosions or traumatic damages is very broad. The most frequently used are composites, whose matrix consists mainly of methacrylate polymers (e.g. bis-GMA, TEGDMA, UDMA, Bis-EMA) and the fillers are $\mathrm{Ba}, \mathrm{Sr}, \mathrm{Zr}$ ground glass with surfaces treated by silane coupling agents and amorphous $\mathrm{SiO} 2$ added primarily for adjusting the thixotropic properties of materials and pigments. These are mainly light-cured materials containing photoinitiators of polymerization reaction, usually camphorquinone (2,3-bornandion), propanedione (1phenyl-1,2-propanedione) or Lucirin TPO (biphenyl (2,4,6-trimetylbenzoyl-diphenylphosphine oxide), often in conjunction with tertiary amine co-initiators.

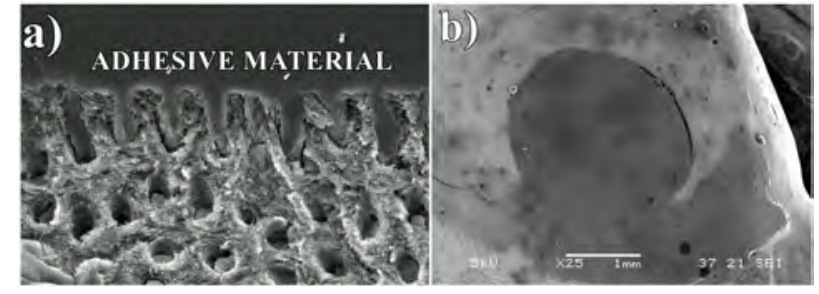

FiguRE 4. a) The adhesive material leaking into the dentinal tubules; b) Damaged marginal seal between the filling material and enamel. (SEM, JSM5500-LV, Jeol, Tokyo, Japan).

They must also contain inhibitors of the polymerization reaction. The hardening of materials occurs by radical polymerisation, when molecules of photoinitiators absorb photons of light from curing lamps forming free radicals, which initiate very fast polymerization reactions. Mainly halogen or LED curing lamps emitting light in the wavelength range 400 to $515 \mathrm{nms}$ are currently used for curing of materials. It is very important that the spectrum of emitted light from the curing light must overlap the absorption spectrum of the photoinitiator present in material to ensure the best possible polymerization [1, 2]. Composite materials are characterized by very good mechanical and aesthetic properties, and are indicated for lateral and front sections of the dental arches. However, these materials are hydrophobic and do not adhere to tooth structure comprising water. Therefore, quality micromechanical binding provides adhesive systems that flow into the previously etched microrelief of dental tissue (Fig. 4h). Adhesive systems include hydrophilic monomers with the ability to wet moist surfaces and bond them with hydrophobic monomers which are chemically combined with a composite material after polymerization.

The main disadvantage of these materials is their shrinkage due to polymerization. This may cause damage to the marginal seal, i.e. loss of contact between the dental tissue and the filling material (Fig. 4 4 ). The polymer materials also show a possible risk of residual free monomers releasing into the surrounding environment, which may give rise to health problems in susceptible individuals, especially to allergic reactions [3] 6 . 


\section{Conclusion}

Further development of polymer composites is driven by efforts to improve their mechanical and aesthetic properties, increase wear resistance, reduce polymerization shrinkage and achieve significant improvements in biocompatibility.

\section{ACKNOWLEDGEMENTS}

This work was supported by grant PRVOUK P28/LF1/6 MŠMT.

\section{REFERENCES}

[1] P. Bradna, L. Comba, J. Froněk, D. Houšová. Kam směřuje vývoj polymeračních lamp? Česká Stomatologie 110(3):61-68, 2010.

[2] J. Froněk. Studium vlivu vlastností polymeračních lamp na vytvrzeni kompozitnich materiálů s různými fotoiniciačnimi systémy. Master's thesis.
[3] M. Syed, R. Chopra, V. Sachdev. Allergic reactions to dental materials-a systematic review. Journal of Clinical and Diagnostic Research 9(10):ZE04 - ZE09, 2015. DOI:10.7860/JCDR/2015/15640.6589.

[4] I. Stoeva, A. Kisselova, M. Zekova. Allergic contact stomatitid from bisphenol-a-glycidyldimethacrylate during application of composite restorations. a case report. Journal of IMAB - Annual Proceeding (Scientific Papers) pp. $45-46,2008$. Book 2.

[5] S. Gupta, P. Saxena, V. Pant, A. Pant. Release and toxicity of dental resin composite. Toxicology

International 19(3):225-234, 2012. DOI:10.4103/0971-6580.103652.

[6] M. Goldberg. In vitro and in vivo studies on the toxicity of dental resin components: a review. Clinical Oral Investigations 12(1):1-8, 2008. DOI:10.1007/s00784-007-0162-8 